\title{
Effects of Posterior Surgical Approach on Cervical Alignment in The Treatment of Cervical Spondylotic Myelopathy
}

\author{
Servikal Spondilotik Miyelopati Tedavisinde Posterior \\ Cerrahi Yaklaşımın Sevikal Dizilime Etkisi
}

Fatih Keskin ${ }^{1}$,

Mehmet Fatih Erdi ${ }^{1}$,

Densel Arac ${ }^{1}$

${ }^{1}$ Necmettin Erbakan University, Meram Faculty of Medicine, Department of

Neurosurgery, Konya, Turkey

Geliş Tarihi/Received: 29 June 2020

Kabul Tarihi/Accepted: 21 October 2020

Address correspondence to: Densel Arac, Necmettin Erbakan University, Meram Faculty of Medicine, Department of Neurosurgery, Konya, Turkey

e-mail: denselarac@hotmail.com

ORCID

Fatih Keskin

https://orcid.org/0000-0001-9398-8908 Mehmet Fatih Erdi

https://orcid.org/0000-0003-3621-6658 Densel Arac https://orcid.org/0000-0003-0616-8835

\begin{abstract}
Öz
Amaç: Dejeneratif servikal spondilotik miyelopatinin tedavisinde kullanılan cerrahi yaklaşımların servikal dizilim ve vertebral kanal çapı ölçümlerine etkisini araştırmak

Hastalar ve Yöntem: Kliniğimizde 2016-2020 yılları arasında servikal spondilotik miyelopati (SSM) ile 45 hasta ameliyat edildi. 5'i kadın 18'i erkek 23 hasta open door laminoplasti ile ameliyat edildi; 4 'ü kadın 18 'i erkek 22 hasta lateral kitle vida füzyonu ile laminektomi ile ameliyat edildi. Hastaların Sagital vertikal aks (SVA) (C2 orta hat ile C7 üst uç plak orta hattı arasındaki mesafe), Cobb açıları (C2 alt uç plakası ve C7 alt uç plakasından geçen hatlar arasındaki açı) ve Vertebra kanal çapı (VCD) (Magnetik rezonans görüntülüme (MRI) görüntülerinden ölçülen vertebral kanal çapı) değerleri ölçüldü. Hastaların ameliyat öncesi dönemde ve ameliyattan 1 yıl sonra toplanan verileri istatistiksel olarak değerlendirildi.

Bulgular: Açık kapı laminoplasti ve mini plak vidası uygulanan hastalarda ameliyat öncesi SVA değeri $17.73+/-18.9$ iken ameliyat sonrası SVA değeri ortalama $12.13+/-12.6$, ameliyat öncesi Cobb açısı 8.4 + /- 13.4olarak bulundu, ameliyat sonrası Cobb açısı ortalama 16,3 +/- 10,02, ameliyat öncesi VCD 4,03 $+/-0.93$, ameliyat sonrası VCD ortalaması ortalama $9.7+/-1.86$ olarak bulundu. Laminektomi ve lateral kitle vida füzyon tekniği uygulanan hastalarda ameliyat öncesi ortalama SVA 15,8 +/- 9,97 iken ameliyat sonrası SVA değeri ortalama 13,7 +/-8,9 oldu, ameliyat öncesi Cobb açısı 10,5 +/- 12,1 iken, ameliyat sonrası Cobb açısı ortalama $13.3+/-11.8$ oldu, ameliyat öncesi VCD $4.3+/-0.73$ bulunmuşken, ameliyat sonrası VCD ortalaması ortalama $9.7+/-1.5$ olarak bulundu.

Sonuç: SSM'Ii hastalarda faset eklem hasarına neden olmayan plak ve vida sistemleri servikal dizilim
\end{abstract} korumasında daha etkilidir.

Anahtar Kelimeler: Servikal spondilotik myelopati, plak ve vida, posterior yaklaşım, servikal hizalama Abstract

Aim: To investigage the effect of surgical approaches used in the treatment of degenerative cervical spondylotic myelopathy on cervical alignment and vertebral canal diameter measurements

Patients and Methods: 45 patients were operated with degenerative cervical sponylotic myelopathy (CSM) in our clinic between 2016 and 2020. 23 of them, including 5 females and 18 males, were operated on with open-door laminoplasty; and 22 of them, including 4 females and 18 males, were operated on with laminectomy and lateral mass screw fusion. Sagittal vertikal Aks (SVA) (Distance between the C2 midline and $\mathrm{C} 7$ superior endplate midline), Cobb angles (The angle between the lines passing through the C2 lower endplate and C7 lower endplate), and Vertebral canal diameter (VCD) (vertebral canal diameter measured from Magnetic resonance imaging (MRI) images) values of patients were measured. Collected data of patients in the preoperative period and 1 year after operation were evaluated statistically.

Results: In patients undergoing open-door laminoplasty and mini-plate screw, the pre-op SVA value was $17.73+/-18.9$ while the post-op SVA value was $12.13+/-12.6$ on average, pre-op Cobb angle was $8.4+/-13.4$ on average, the post-op Cobb angle was $16.3+/-10.02$ on average, pre-op VCD was $4.03+/$ 0.93 , the post-op VCD mean was $9.7+/-1.86$ on average. In patients undergoing laminectomy and lateral mass screw fusion technique, the mean pre-op SVA was $15.8+/-9.97$, while the post-op SVA value was $13.7+/-8.9$ on average, pre-op Cobb angle was $10.5+/-12.1$ on average, while the post-op Cobb angle was $13.3+/-11.8$ on average, pre-op VCD was $4.3+/-0.73$, the post-op VCD mean was found to be $9.7+/-1.5$ on average.

Conclusion: Plate and screw systems not causing facet joint damage use in patients with CSM are more effective in the cervical alignment protection

Key words: Cervical spondylotic myelopathy, plate and screw, posterior approach, cervical alignment,

Cite this article as: Keskin F, Erdi MF, Arac D. Effects of Posterior Surgical Approach on Cervical Alignment in The Treatment of Cervical Spondylotic Myelopathy. Selcuk Med J 2021;37(1): 32-38

Disclosure: None of the authors has a financial interest in any of the products, devices, or drugs mentioned in this article. The research was not sponsored by an outside organization. All authors have agreed to allow full access to the primary data and to allow the journal to review the data if requested. 


\section{INTRODUCTION}

Cervical spondylosis is a progressive, insidious, and degenerative disease that starts in the intervertebral disc and continues in the surrounding bone and soft tissues (1). Cervical spondylotic myelopathy (CSM); Is a clinical condition that causes myelopathy because of suppression and compression of the cervical cord (2) and is one of the most severe complications of cervical spondylosis (3). Cervical vertebral canal diameter between $\mathrm{C} 3-\mathrm{C} 7$ is $17-18 \mathrm{~mm}$ and cervical cord diameter between $\mathrm{C} 1-\mathrm{C} 7$ is $10 \mathrm{~mm}$. As a result, $2 / 3$ of the cervical canal between $C 1$ and $C 3$ is free and $1 / 4$ of that between $\mathrm{C} 4$ and $\mathrm{C} 7$ is free. Based on these values, the vertebral canal is quite wide compared to the cord and the emergence of spondylosis findings is only possible with congenital stenosis and $12 \mathrm{~mm}$ below the vertebral canal diameter sagittally (4).

The most common signs and symptoms in CSM patients are thenar-hypothenar atrophy, hyperreflexia, sensory loss, spastic paresis, ataxia, and pathological reflexes due to the first motor lesion $(3,5,6)$. The generally accepted criteria in the surgical treatment of these patients are moderate and severe symptoms and findings, positive imaging findings, and the Japanese orthopedic association spondylotic myelopathy assessment scale 10 and below (7). Among the surgical approaches in CSM patients; Anterior discectomy, corpectomy, anterolateral oblique corpectomy, posterior laminectomy, and laminoplasty are performed (8). The aim of this study is to evaluate the surgical approach selected in the cases of degenerative cervical spondylomyelopathy performed in our clinic. Also, we would like to discuss the effect of the chosen surgical methods on postoperative findings according to preoperative findings of patients.

\section{PATIENTS AND METHODS}

In our clinic between 2016 and 2020, 45 patients were evaluated and operated with the diagnosis of CSM. 36 of these patients were male and 9 were female. Our criteria for diagnosing CSM: The presence of motor and sensory disorders in the extremities, Oddi sphincter dysfunction and myelomalacia accompanied by suppression of the cervical cord in $\mathrm{X}$-ray, MRI, and tomography images. All the patients received bone density examination before surgery, and none of them had severe osteoporosis, with $\mathrm{T}$ value $>-2,5$. In patient selection, rheumatological, traumatic, congenital deformities, and infectious cases were excluded from the study. The study protocol was approved by Necmettin Erbakan University Meram Faculty of Medicine, (Decision No: 2020/2702).

Before surgery, all patients were informed of the advantages and disadvantages of the surgical approaches without any bias, and they were allowed to make their own choice. A posterior surgical approach is to be performed according to the symptoms of patients and the results of tomography and magnetic resonance imaging (MRI). We divided our patients into two groups according to the surgical technique; these are group 1:23 patients, including 5 females and 18 males, were operated with opendoor laminoplasty with mini-plate screw; and group 2: 22 patients, including 4 females and 18 males, were operated with laminectomy and lateral mass screw fusion. The patients were followed up for 2 years based on neurological examination and imaging methods after surgery.

\section{Surgical procedures}

Open door laminoplasty: Patients' heads and necks were fixed using a Mayfield head clamp in a prone position under general anesthesia. Subsequently, the layers were passed through the median vertical skin incision between $\mathrm{C} 3$ and $\mathrm{C} 7$ from the posterior of the neck. Paravertebral muscles were bilaterally subperiosteal dissected. According to the patient's complaint, the affected side of the lamina was determined as the open side and the opposite side as the door shaft. A groove was made at the boundary between bilateral facet joints and laminae. The entire layer of lamina was severed on the open-door side, and the inner layer of cortex was preserved on the door-shaft side. The ligamentum flavum were severed at open-door side. Centerpiece mini-plates of appropriate length were installed between the lateral mass and opened lamina; the opened lamina was held with the claw-shaped clamp and immobilized with one to two titanium screws; another two titanium screws were used to immobilize the lateral mass on the open-door side.

Total laminectomy and fusion: Patients' heads and necks were fixed using a Mayfield head clamp in a prone position under general anesthesia. Subsequently, the layers were passed through the median vertical skin incision between $\mathrm{C} 3$ and C7 from the posterior of the neck. Paravertebral muscles were bilaterally subperiosteal dissected. After the facet joints were exposed, $14-16 \mathrm{~mm}$ long, $3.5 \mathrm{~mm}$ thick lateral mass screws were placed under specified scopy control and the rods were fixed in a position suitable for cervical lordosis. The determined laminas 


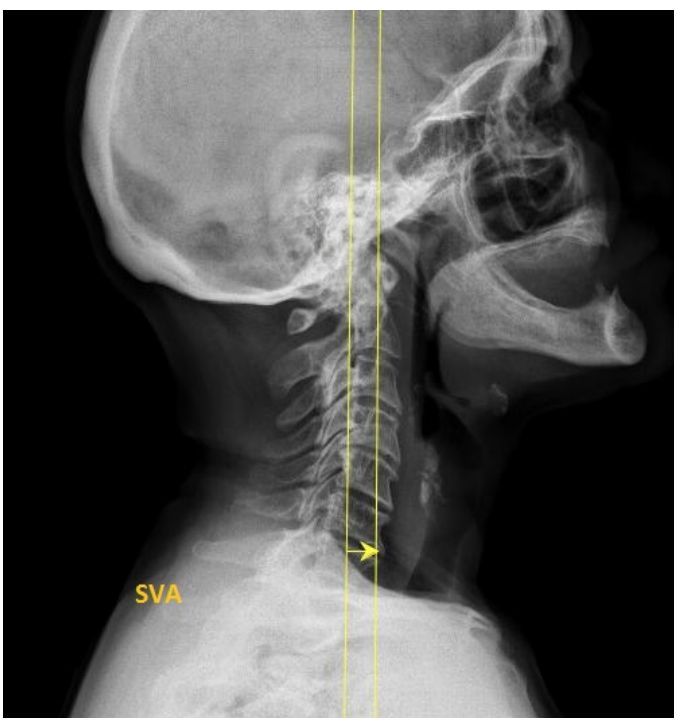

Figure 1. Distance between the $\mathrm{C} 2$ midline and $\mathrm{C} 7$ superior endplate midline

were totally removed with the facet joint and the lamina junction to be the limit and subsequent flavectomy was performed. It was seen that the dura expanded and relaxed.

Antibiotics were given prophylactically for up to $48 \mathrm{~h}$ after surgery. Considering larger surgical incisions and higher drainage volume, the drain was kept for more than $48 \mathrm{~h}$ in all patients. If the drainage volume is less than $50 \mathrm{ml} / 24 \mathrm{~h}$, the drain will be removed. Patients were assisted in off-bed movements wearing a cervical collar. They began to take exercises of posterior cervical muscles after 3 to 4 weeks.

\section{RESULTS}

Group 1 included 18 male and 5 female patients, with the mean age of men and women being 64.6 and 58.2 , respectively. Group 2 included 18 men and 4 women, while the average age of men was 63.1 , while the average age of women was 73. SVA (Distance between the $\mathrm{C} 2$ midline and $\mathrm{C} 7$ superior endplate

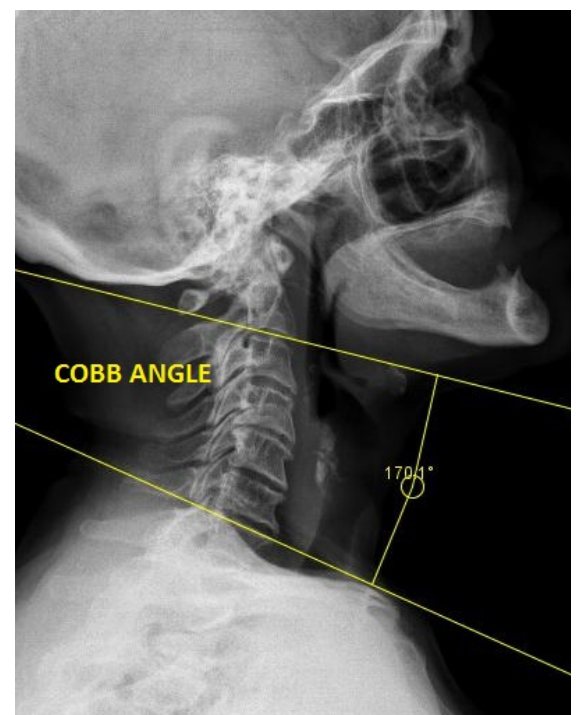

Figure 2. The angle between the lines passing through the C2 lower endplate and C7 lower endplate

midline) (Figure 1), Cobb angles (The angle between the lines passing through the $\mathrm{C} 2$ lower endplate and C7 lower endplate) (Figure 2), and VCD (vertebral canal diameter measured from MRI images) values of patients were measured in preoperative and postoperative 1st year and statistical comparison was made (Figure 3). All data were analyzed using SPSS version 22 statistical software. In patients undergoing open-door laminoplasty and mini-plate screw, the pre-op SVA value was $17.73+/-18.9$ while the post-op SVA value was $12.13+/-12.6$ on average, and pre-op and post-op a statistically significant difference was detected in the SVA value comparison ( $p<0.05$ ). While the pre-op Cobb angle was $8.4+/-13.4$ on average, the post-op Cobb angle was $16.3+/-10.02$ on average, and there was a statistically significant difference between the pre-op and post-op Cobb angle $(p<0.05)$. While the mean pre-op VCD was 4.03 $+/-0.93$, the post-op VCD mean was $9.7+/-1.86$ and a statistically significant difference was found between

Table 1. Open Door Laminoplasty

\begin{tabular}{lllll}
\hline & N & Minimum & Maximum & Mean \\
\hline Pre-op SVA & 23 & $-13,02$ & 55,20 & 17,7370 \\
Post-op SVA & 23 & $-7,19$ & 32,54 & 12,1365 \\
Pre-op Cobb & 23 & $-19,50$ & 31,80 & $8,4043,92993$ \\
Post-op Cobb & 23 & $-4,90$ & 34,00 & 12,65558 \\
Pre-op VCD & 23 & 2,39 & 6,14 & 16,3391 \\
Post-op VCD & 23 & 6,62 & 13,73 & 4,0348 \\
\hline
\end{tabular}

A statistically significant difference was observed between pre-op and post-op SVA values $(p<0.05)$. A statistically significant difference was observed between pre-op and post-op COBB angles $(p<0.05)$. A statistically significant difference was observed between pre-op and post-op VCD values $(p<0.05)$. 


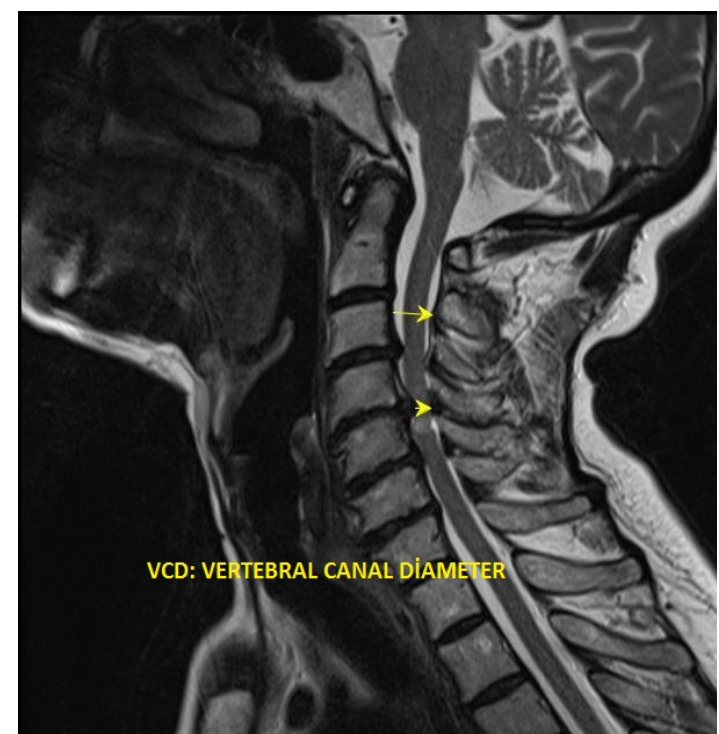

Figure 3. Vertebral canal diameter measured from MR images

the pre-op and post-op VCD values $(p<0.05)$ (Table 1)

In patients undergoing laminectomy and lateral mass screw fusion technique, the mean pre-op SVA was $15.8+/-9.97$, while the post-op SVA value was $13.7+/-8.9$ on average, and pre-op \& post-op a statistically significant difference was detected in the SVA value comparison ( $p<0.05)$. The pre-op Cobb angle was $10.5+/-12.1$ on average, while the post-op Cobb angle was $13.3+/-11.8$ on average, and there was a statistically significant difference between the pre-op and post-op Cobb angle. $(p<0.05)$. Meanwhile the mean pre-op VCD was $4.3+/-0.73$, the post-op VCD mean was found to be $9.7+/-1.5$, and there was a statistically significant difference between the preop and post-op VCD values ( $p<0.05)$ (Table 2$)$. In statistical calculation between groups, there was no statistically significant difference in sagittal vertical

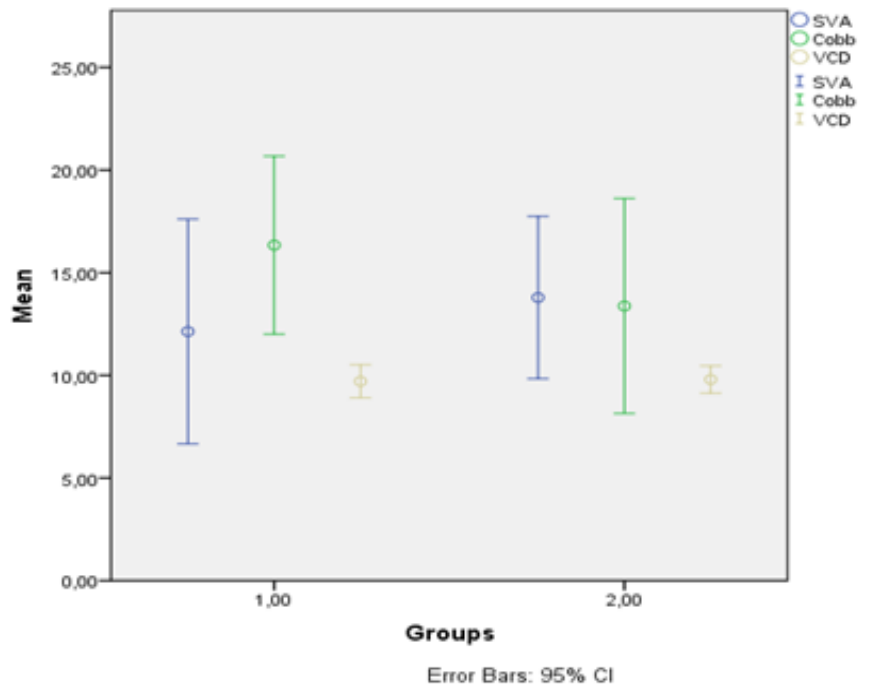

Figure 4. SVA, Cobb angle and VCD values measured in post-op 1st year between group 1 and group $2(p>0.05)$

alingment (SVA), Cobb angle and Vertebral canal diameter VCD values measured in the post-op 1st year between group 1 and group $2(p>0.05)$ (Table 3$)$ (Figure 4).

\section{DISCUSSION}

While determining the approach in the surgical treatment of CSM, some criteria should be considered (9-15) including; spinal cord compression in anterior and/or posterior, which and how many cervical levels of compression, cervical alignment lordosis or kyphosis, presence of instability, the general condition of the patient, concomitant diseases and presence of risk factors, bone status of the patient, surgeon experience and preference. In cases where compression is from the anterior, in patients with cervical lordosis or spinal alignment flattening, a posterior surgical approach can be applied $(11,16,17)$. In patients with cervical

Table 2. Laminectomy and Lateral Mass Screw Fusion

\begin{tabular}{lllll}
\hline & N & Minimum & Maximum & Mean \\
\hline Pre-op SVA & 22 & $-5,60$ & 40,51 & 15,8427 \\
Post-op SVA & 22 & $-2,80$ & 35,60 & 13,7886 \\
Pre-op Cobb & 22 & $-21,20$ & 24,50 & 10,5264 \\
Post-op Cobb & 22 & $-18,50$ & 25,60 & 13,91501 \\
Pre-op VCD & 22 & 3,02 & 6,01 & 13,13345 \\
Post-op VCD & 22 & 7,40 & 12,45 & 4,3200 \\
\hline
\end{tabular}

A statistically significant difference was observed between pre-op and post-op SVA values $(p<0.05)$. A statistically significant difference was observed

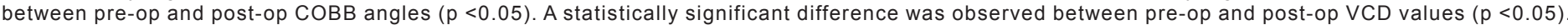




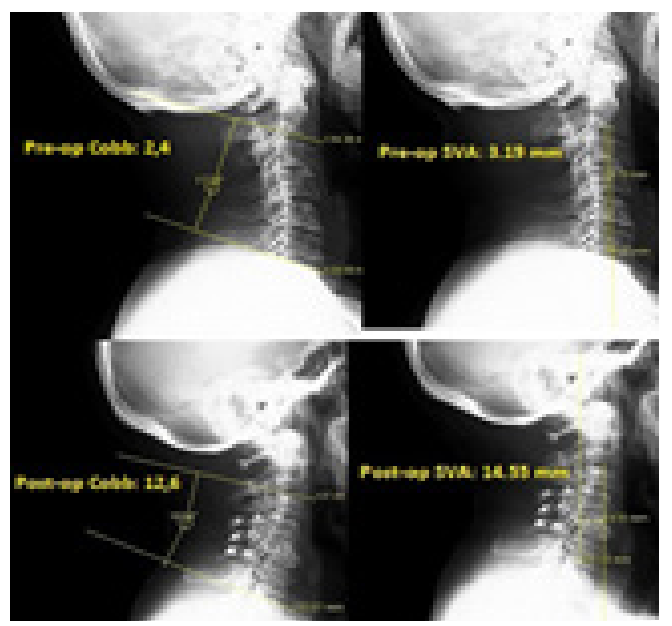

Figure 5. Shows pre-op and post-op SVA and Cobb angles of posterior open door laminoplasty and miniplate screw fusion

kyphosis, applying the posterior surgical approach may decrease the surgical benefit and increase the risk of complications. In cases of kyphosis, it is difficult to maintain a normal lordotic condition with a posterior approach, and compression continues in the region where there is kyphosis on the background of spondylosis, thus the desired surgical success cannot be achieved and the risk of complication increases $(11,17)$. Application of laminectomy alone, which is one of the posterior approaches, may cause cervical alignment disruption and kyphosis, especially by removing excess facet joint $(11,16,17)$. Cervical sympathetic chain injury, recurrent laryngeal nerve injury, graft and plate complications, dysphagia, esophageal injury, vascular injury, epidural hematoma are complications that can be seen in anterior approaches, especially in corpectomy or long segment surgery. While kyphosis and instability complications are predominant in the posterior approach, these possibilities can be reduced to a very low percentage by using posterior instrumentation and laminoplasty

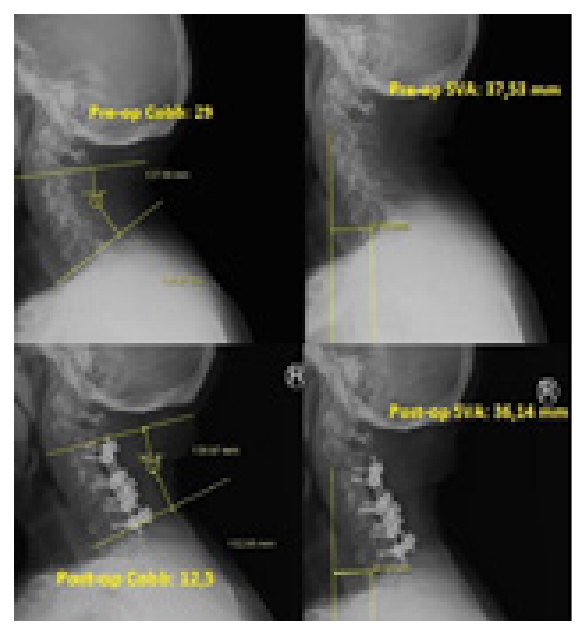

Figure 6. Shows pre-op and post-op SVA and Cobb angles of posterior laminectomy and lateral mass screw fusion

plates and screws. When we considered other complications of the posterior approach; Fehlings et al. (18) reported in a multicenter prospective study that there were no differences between anterior and posterior approaches in clinical results, complications, and international scores.

In deciding anterior and posterior interventions, it is not only the compression of the anterior or posterior but also the segments of the compression; For example, the difficulty of anterior interventions and high complications in the cervical upper segments are known. When three or more segments are involved, the posterior cervical approach is preferred to ensure clinical outcomes and safety (19-21).

Matsunaga et al. (22) retrospectively analyzed the cervical alignment of 64 patients who underwent laminoplasty and 37 patients who underwent laminectomy for CSM, and they reported that postoperative kyphosis or swan neck deformity is more common after laminectomy alone (34\%) versus laminoplasty $(7 \%)$ with a follow-up of 5 years.

Table 3. Post-op SVA, Cobb angle and VCD values of group 1 and group 2

\begin{tabular}{llllll}
\hline & VAR00001 & N & Mean & Std. Deviation & Std. Error Mean \\
\hline SVA & Grup 1 & 23 & 12,1365 & 12,65558 & 2,63887 \\
& Grup 2 & 22 & 13,7886 & 8,91501 & 1,90069 \\
Cobb & Grup 1 & 23 & 16,3391 & 10,02074 & 2,08947 \\
& Grup 2 & 22 & 13,3759 & 11,81255 & 2,51844 \\
VCD & Grup 1 & 23 & 9,7087 & 1,86005 &, 38785 \\
& Grup 2 & 22 & 9,7986 & 1,50702 &, 32130 \\
\hline
\end{tabular}

In the comparison between group 1 and group 2, no significant difference was found between post-op SVA, Cobb angle, and VCD values between groups $(P>0.05)$. 
Cervical laminectomy and fusion offer the advantage to stabilize the decompressed segment in a lordotic posture while preventing segmental instability, thereby allowing for a more expansive decompression (23). In our study, we examined 45 patients with CSM who operated with two different posterior techniques (Figure 5,6). Posterior open-door laminoplasty and mini-plate screw fusion surgery were performed in 23 patients in group 1, while posterior laminectomy and lateral mass screw fusion technique were applied to 22 patients in group 2, and cervical SVA, Cobb angle, and vertebral canal diameter (VCD) values of the patients discussed in the groups were evaluated statistically.

In the SVA measurements showing the forward tilt of the head, there was a statistically significant decrease in the post-op mean value of 5.6 in group 1 and $2.1 \mathrm{~mm}$ in group 2 . In the measurements made by evaluating the Cobb angle as normal between 10$40^{\circ}$, hyper-lordotic if $>40^{\circ}$, hypo-lordotic between $0-10^{\circ}$, and kyphotic if less than 0 degrees (24). While the post-op Cobb angle in group 1 was 16.3 degrees, in group 2 the Cobb angle was found to be 13.3 degrees on average. Providing adequate cervical lordosis and a horizontal view that does not require a forward tilt of the head are as important surgical goals as decompression. As another operating benefit criterion, expanded (VCD) was achieved on MRI images taken in post-op 1st year of patients. There was a statistically significant increase in VCD change, $5.67 \mathrm{~mm}$ in post-op mean value in group 1 and 5.47 $\mathrm{mm}$ in group 2 .

When the data of both groups are compared, although there is no statistically significant result between SVA, Cobb angle, and VCD values, when we look at the average numerical values, it is seen that better results are obtained in group 1 compared to group 2.

\section{CONCLUSION}

It should be kept in mind that a good calculation of the lamina facet border in posterior approaches and damage to the facet joints can lead to kyphosis. Complications are less common than the anterior approach: Lack of important structures such as esophagus, trachea, carotid artery, internal jugular vein; Providing fusion with plate and screw systems to be applied and not causing facet joint damage, it was seen that the posterior approach is an appropriate method in cases of intervention to 3 or more cervical segments.
Conflict of interest: Authors declare that there is no conflict of interest between the authors of the article.

Financial conflict of interest: Authors declare that they did not receive any financial support in this study.

Address correspondence to: Densel Arac, Necmettin Erbakan University, Meram Faculty of Medicine, Department of Neurosurgery, Konya, Turkey

E-mail: denselarac@hotmail.com

Phone number: +90 (332) 2237783

\section{REFERENCES}

1. Kojima T, Waga S, Kubo $\mathrm{Y}$, et al. Anterior cervical vertebrectomy and interbody fusion for multilevel spondylosis and ossification of the posterior longitudinal ligament. Neurosurgery 1989;24:864-71.

2. Clark CR. Differental diagnosis and non-operative management. In:Frymoyer JW, ed. The Adult Spine: Principles and Practice. 2nd ed. Philadelphia: LippincottRaven Publishers 1997:1323-47.

3. Şahin N, Berker N. Servikal spondilotik myelopati. Türk Fiz Tıp Rehab Derg 2006;52:42-7.

4. Fehlings MG, Skaf G. A review of the pathophysiology of cervical spondylotic myelopathy with insights for potential novel mechanisms drawn from spinal cord injury. Spine 1998;23(24):2730-7.

5. Maurice V, Allan HR. Pain in the back, neck and extremites, Adams and Victor's principles of neurology. Newyork; Mc GrawHill, Medical Pub Division 2001:1542-68.

6. Montogomery DM, Bower RS. Cervical spondylotic myelopathy. Clinical syndrome and natural history. Orthop Clin North Am 1992;23(3):487-93.

7. Yoshimatsu H, Nagata K, Goto H, et al. Conservative treatment for cervical spondylotic myelopathy: Prediction of treatment effects by multivariate analysis. Spine 2001;1(4):269-73.

8. Dvorak J. Epidemiology, physical examination and neurodiagnostics. Spine 1998;23:2663-73.

9. Nadiri S. Servikal spondilotik miyelopatide cerrahi yaklaşımın seçimi. Türk Nöroşirurji Dergisi 2000;10:137-43.

10. Erol F. Servikal spondilotik myelopatide klinik, tanı ve ayırıcı tanı. In: Koçak RK, ed. Servikal dejeneratif disk hastalığı ve üst ekstremite tuzak nöropatileri. Ankara, Buluş Tasarım ve Matb 2009;234-44.

11. Zileli M. Servikal spondilotik myelopatide laminektomi. In: Koçak RK, ed. Servikal dejeneratif disk hastalığı ve üst ekstremite tuzak nöropatileri. Ankara, Buluş Tasarım ve Matb 2009;285-96.

12. Çaylı SR. Servikal spondilotik myelopatide anterior dekompresyon ve füzyon. In: Koçak RK, ed. Servikal dejeneratif disk hastalığı ve üst ekstremite tuzak nöropatileri. Ankara, Buluş Tasarım ve Matb 2009:262-9.

13. Alvin MD, Lubelski $D$, Benzel $E C$, et al. Ventral fusion versus dorsal fusion. Determining the optimal treatment for cervical spondylotic myelopathy. Neurosurg Focus 2013;35:E5.

14. König SA, Spetzger U. Surgical management of cervical spondylotic myelopathy - indications for anterior, posterior or combined procedures for decompression and stabilisation. Acta Neurochir 2014;156:253-8.

15. Dalbayrak S. Posterior longitudinal ligaman ossifikasyonu. 
In: Koçak RK, ed. Servikal dejeneratif disk hastalığı ve üst ekstremite tuzak nöropatileri. Ankara, Buluş Tasarım ve Matb 2009:245-61.

16. Janssen M, Bono C, Sasso R, et al. Anterior versus posterior surgical approaches to treat cervical spondylotic myelopathy. Outcomes of the prospective multicenter AOSpine North America CSM study in 264 patients. Spine 2013;38:2247-52.

17. Fehlings MG, Barry S, Kopjar B, et al. Anterior corpectomy versus posterior laminoplasty for multilevel cervical myelopathy: A systematic review and meta-analysis. Eur Spine J 2014;23:362-72.

18. Fehlings MG, Barry S, Kopjar B, et al. Anterior versus posterior surgical approaches to treat cervical spondylotic myelopathy: Outcomes of the prospective multicenter AOSpine North America CSM study in 264 patients. Spine (Phila Pa 1976) 2013;38(26):2247-52.

19. Chen H, Deng Y, Li T, et al. Clinical and radiography results of mini-plate fixation compared to suture suspensory fixation in cervical laminoplasty: A five-year follow-up study. Clin Neurol Neurosurg 2015;138:188-95.
20. Yeh KT, Yu TC, Chen IH, et al. Expansive open-door laminoplasty secured with titanium miniplates is a good surgical method for multiple-level cervical stenosis. J Orthop Surg Res 2014;9:49.

21. Lin $\mathrm{X}$, Chen $\mathrm{K}$, Tang $\mathrm{H}$, et al. Comparison of anchor screw fixation versus mini-plate fixation in unilateral expansive open-door laminoplasty for the treatment of multi-level cervical spondylotic myelopathy. Medicine (Baltimore) 2018;97(49):e13534.

22. Matsunaga S, Sakou T, Nakanisi K. Analysis of the cervical spine alignment following laminoplasty and laminectomy. Spinal Cord 1999;37:20-4.

23. Bakhsheshian J, Mehta VA, Liu JC. Current diagnosis and management of cervical spondylotic myelopathy. Global Spine J 2017;7(6):572-86.

24. Dağlı M, Er U, Şimşek S, et al. Late results of anterior cervical discectomy and fusion with interbody cages. Asian Spine J 2013;1:34-7. 